\title{
Poor data hampers East-West cooperation
}

Munich. Scientific cooperation between Eastern and Western Europe is being hindered by a lack of reliable data about science and technology activities in Central and Eastern Europe, according to the parliamentary assembly of the Council of Europe, which last week passed a resolution calling for the establishment of a system to collect such statistics.

The assembly also called for cooperation programmes to give priority to increasing support for projects facilitating the conversion of military research projects to civil goals, pointing out that efforts to do this have so far been notably unsuccessful.

Such resolutions are not binding on the Council's 38 member states. But a spokesman for the Council's secretariat says that they are intended to focus the attention of the West on the serious problems facing many Central and Eastern European countries as they attempt to reform their scientific efforts after the fall of communism.

The assembly's decisions follow a report from the Council's Committee on Science and Technology pointing to the disappointingly slow transformation of Eastern European research structures into the standard Western model, which it describes as being based on openness, competitiveness and the independent assessment of the quality of research activities.

According to the report, which acknowledges considerable differences in the rate of reform in individual countries, resistance to reform has been fuelled by, among other factors, the frequent unwillingness of academies of sciences to give up the many privileges they enjoyed in communist times, and by a 'culture of secrecy' which resists pressures for public accountability.

Central and Eastern Europe still has

need of the West to help the reform process, it says. But such help should be given in terms of concrete investment - that is, financial and material resources - rather than merely advice. The committee claims that Central and Eastern European countries are starting to feel patronized by the well-meaning gestures of Western organizations who over the past few years have sent numerous delegations to give advisory seminars or pass judgement on quality of research but have brought little in terms of money or scientific equipment.

The resolution passed last week also calls for a clearer focus for cooperation agreements, and stresses the urgency of projects to 'convert' military research.

In addition, research agreements have been hindered by a continued deterioration

\section{Materials advice for German research}

Munich. Germany is to set up a national advisory group for materials sciences in the light of criticism from its Science Council, the Wissenschaftsrat, of the lack of communication both among research institutes and between research institutes and industry. The report blames this lack of coordination for Germany's failure to remain internationally competitive in the development of industrially relevant new materials.

Franz Mayinger, an engineer from the Technical University of Munich who headed the committee that prepared the report, says that the new advisory group, which is expected to be financed initially by the federal research ministry (BMBF) before finding a home within industry, will seek to encourage interdisciplinary coordination and to promote the more efficient transfer of tech-

\section{Russia approves gene therapy research grants}

Moscow. The Russian Human Genome Project (RHGP), recently the subject of international scientific concern (see Nature $374, \mathbf{5 8 0}$; 1995), has overcome its organizational difficulties and made an important step forward with the approval of grants to a number of research projects aimed at the development of gene therapy.

The grants cover various fields. Four deal with the development of approaches to the introduction of dystrophin gene and/or its 'minigenes' into muscles as a possible treatment for Duchenne and Becker myodystrophies. Two are devoted to the use of antisense genetic constructions as potential tools for anticancer therapy, and one to transferring the human apolipoprotein gene into liver cells both in vitro and in vivo as a possible approach to atherosclerosis gene therapy.

Special attention is given to the

development and application of 'ballistic' techniques for inserting genes into their targets. "This is a field in which Russian science has a clearly defined priority," says Lev Kisselev from the Engelhardt Institute of Molecular Biology in Moscow, who was recently appointed head of the RHGP. The RHGP council has also decided to set up a committee to decide on the conditions under which human gene therapy should be carried out in Russia.

The success of the gene therapy projects will depend heavily on the amount of money that the Russian government, including the Ministry of Science and Technological Policy, agrees to allocate for the RHGP as a whole, and to the human gene therapy programme in particular. Until now, funding for the RHGP has been very modest, totalling only about US\$500 000 for the whole 1995 .

Carl Levitin in the research infrastructure in Central and Eastern Europe, as well as by severe bureaucratic hurdles. The report also hints at problems caused by uncertainties over where Western money goes once it arrives in the East, due to inadequate public records. This would be helped by the creation of a system, proposed in the resolution, of formal statistical accounting.

But there is one hopeful sign in the report. New estimates of the size of the East-to-West brain drain suggests that the problem may have been exaggerated in the past. After the major wave of emigration of scientists in the early $1990 \mathrm{~s}$, the situation has now stabilized, it says, and current loss to the West is believed to total less than 10 per cent of the total research and development capacity in each country. Alison Abbott

nology between laboratories and industry. Its members will include both scientists and local and federal government officials.

The expert committee spent the past 18 months reviewing the work of 34 of the country's publicly funded non-university research institutes that undertake materials research, and concluded that standards varied widely. The large Max Planck Institute for Polymer Research in Mainz, for example, was singled out for praise, while the Fraunhofer Institute for Solar Energy Systems in Freiburg was heavily criticized for the low quality of its work.

There was also heavy criticism of the materials science programme within the struggling national research centre at Karlsruhe, recently renamed the Forschungszentrum Karlsruhe. The centre was established in the 1950 s as a nuclear research centre, and has since been forced to turn to new research directions, but the commission said that its material science efforts were too diverse in their aims and thus unproductive. This judgement puts more pressure on the Karlsruhe centre which, in the eyes of many politicians, has so far been unsuccessful in making a smooth transition from nuclear to non-nuclear research.

Unlike previous Wissenschaftsrat reports, this one does not recommend the closure or contraction of any research institutes. But the report does make the usual plea for funds. The long-term nature of new materials development, which can take up to 20 years, requires more generous resource commitments from the BMBF, which usually restricts project funding to five years, says Mayinger. He adds that the advisory group will also address the industry's apparent lack of interest in funding new materials research because of pressure arising from Germany's current economic recession.

A. A. 